\title{
Early interventions to prevent mental disorders - learning lessons from the field of psychosis
}

\section{Intervenção precoce para a prevenção de transtornos mentais - aprendendo liçóes do campo das psicoses}

Prevention has always been a key focus of medicine. Although prevention at the primary, secondary, and tertiary levels is a well-established concept in all areas of medicine, it was only during the 1970s that the first initiatives on the prevention of mental disorders were initiated ${ }^{1}$. Some of the pioneering prevention efforts in mental health focused on individuals at risk for psychosis. As a consequence, the literature on how to best identify and treat those at high risk for psychosis is more substantial than that for any other mental disorder.

In this volume of Revista Brasileira de Psiquiatria, leading researchers in this field review data concerning the identification of individuals at high risk for the development of psychosis and bipolar disorders and summarize the available evidence on the efficacy of the broad range of preventive strategies that have been tested to date.

One of the key problems about prevention in the field of mental health consists on how to best identify those that will develop mental disorders in the future. Mental disorders have multiple determinants and human behavior is too complex to be understood in a dichotomous fashion such as the presence or absence of illness. Considering the high levels of stigma associated with psychiatric interventions, accuracy in selecting those who would benefit most from preventive actions is crucial. The first article in this issue, by Gee and Cannon, presents a critique of the criteria currently in use to identify individuals at "ultra-high-risk" for psychosis. Current estimates indicate that only 30 to $40 \%$ of those who meet these criteria will become psychotic within 2-3 years of follow-up. We certainly need to do better than this, as a false positive rate of 60 to $70 \%$ is a matter of great concern. There is reason for optimism, however, as emerging findings from cohort studies indicate that attenuated positive symptoms, poor social functioning, and genetic risk for schizophrenia appear to be the most consistent predictors of conversion to psychosis, and that algorithms combining these indicators might achieve a positive predictive power $\geq 80 \%$.

Yung and Nelson review the pros and cons of including an "at-risk for psychosis" category in the forthcoming edition of the Diagnostic and Statistical Manual of Mental Disorders (DSM-V). The authors state that the evidence for specific intervention strategies for this population is moderate at best and that it would be premature to include this category in DSM-V. Yung and Nelson also discuss the series of intervention studies in this population, including the use of low dose antipsychotic medication, cognitive therapy, and omega-3 fatty acids. It is noteworthy that it was at their University of Melbourne that the first clinic for help-seeking people at high risk of schizophrenia was founded.

The review by McGuire and colleagues focuses on the effectiveness of preventive interventions for psychosis. The authors suggest that efforts at the level of primary prevention may lead to better secondary prevention. Remarkably, individuals followed-up by an Outreach and Support service in South London (OASIS) who later developed psychosis had a mean duration of untreated psychosis (DUP) of only around 10 days, compared with a DUP of 12 months in patients from the same geographic area who did not participate in the OASIS program.

Galdos and colleagues describe data of an original study in which they attempted to determine whether specific neurocognitive impairments observed in patients with psychotic disorders might be responsible for their misrepresentations of the social world. While we wait for future studies, the identification of subcomponents of the psychotic phenotype, such as core deficits in the realm of social cognition, may have a heuristic value in detecting key alterations very early in the course of psychotic illness or in individuals at risk. This paper is an elegant reminder that if we are to improve our accuracy in predicting future mental disorders, we might well make use of our growing knowledge on their underlying neural circuitry and cognitive features. Next, Taylor and colleagues extend the concepts of risk and prevention beyond psychosis and review available literature on how close we are to being able to predict who will convert to bipolar disorder. The final review presents a summary of ongoing initiatives for the prevention of mental disorders across Latin America.

Mental, behavioral, and developmental disorders are a major public-health concern. Mental disorders are highly prevalent, most frequently start at childhood, respond only partially to currently available treatment options, tend to have a chronic course and are often incapacitating. Fortunately, initiatives designed to prevent psychosis and other mental disorders have emerged from around 
the world in recent years. This is in line with a paradigm shift in psychiatry that places a greater emphasis on the developmental processes that underlie mental disorders. This issue is not just an opportunity to become acquainted with the best evidence on how to offer good care for those at risk for psychosis and bipolar disorder, but also a remarkable opportunity to reflect on the future of our field as we seek to find ways to prevent the emergence of mental disorders ${ }^{2}$.

Taís S. Moriyama

\section{Eurípedes C. Miguel} James Leckman

\section{References}

1. World Health Organization - WHO. Prevention and Promotion in Mental Health. Geneva, Switzerland: World Health Organization; 2002.

2. Miguel EC, Mercadante MT, Grisi S, Rohde LA. The National Science and Technology Institute in Child and Adolescence Developmental Psychiatry: a new paradigm for Brazilian psychiatry focused on our children and their future. Rev Bras Psiquiatr. 2009;31(2):85-8.

\section{Disclosures}

\begin{tabular}{|c|c|c|c|c|c|c|c|}
\hline $\begin{array}{l}\text { Writing } \\
\text { group } \\
\text { member }\end{array}$ & Employment & $\begin{array}{l}\text { Research } \\
\text { grant }^{1}\end{array}$ & $\begin{array}{c}\text { Other } \\
\text { research } \\
\text { grant or } \\
\text { medical } \\
\text { continuous } \\
\text { education }\end{array}$ & $\begin{array}{l}\text { Speaker's } \\
\text { honoraria }\end{array}$ & $\begin{array}{c}\text { Ownership } \\
\text { interest }\end{array}$ & $\begin{array}{c}\text { Consultant/ } \\
\text { Advisory } \\
\text { board }\end{array}$ & Other $^{3}$ \\
\hline $\begin{array}{l}\text { Tais S. } \\
\text { Moriyama }\end{array}$ & - & - & $\begin{array}{c}\text { CNPq } \\
\text { Eli-Lilly } \\
\text { Janssen- } \\
\text { Cilag }\end{array}$ & - & - & - & - \\
\hline $\begin{array}{l}\text { Eurípedes C. } \\
\text { Miguel }\end{array}$ & $\begin{array}{l}\text { IPq-HC } \\
\text { FMUSP }\end{array}$ & $\begin{array}{c}\text { CNPq } \\
\text { FAPESP }\end{array}$ & - & - & - & - & - \\
\hline $\begin{array}{l}\text { James } \\
\text { Leckman }\end{array}$ & $\begin{array}{c}\text { National } \\
\text { Institute of } \\
\text { Health } \\
\text { Tourette } \\
\text { Syndrome } \\
\text { Association }\end{array}$ & - & - & - & $\begin{array}{l}\text { Jonh Wiley } \\
\text { and Sons } \\
\text { Oxford } \\
\text { University } \\
\text { Press } \\
\text { McGraw-Hill }\end{array}$ & - & - \\
\hline
\end{tabular}

\section{* Modest}

** Significant

*** Significant: Amounts given to the author's institution or to a colleague for research in which the author has participation, not directly to the author.. 